\title{
THE RECOVERY OF DOWRY IN ROMAN LAW
}

The recent article by R. P. Saller on Roman dowry in the Principate ${ }^{1}$ makes some interesting and important suggestions about the function of dowry and its role in the devolution of property. I am in broad agreement with a good deal of what he says, and would not dispute his views that dowry was, as shown by the requirement of collatio dotis, regarded as in a sense part of a woman's patrimony, and that the rules for the recovery of dowry show that the purpose of giving dowry was not held to rest on one single principle, but included provision both for the expenses of the wife's maintenance during marriage and for a possible remarriage after divorce or widowhood. However, his remarks on both points need some qualification and amplification. Briefly, I hope to show (i) that the oddities and anomalies noticed by Saller in the rules governing the recovery of dowry at the end of a marriage are apparent rather than real, since these rules rest, not on conflicting views about the purpose of dowry, but on the fact that the husband had full legal ownership of the dowry during marriage, together with the right of the wife or her pater to an actio rei uxoriae for recovery of dowry; (ii) that the rules for collatio dotis applied only if the woman herself chose to claim a share in her father's estate on intestacy beyond the amount of her dowry; (iii) that the use of the dowry for the wife's support was an equitable, rather than a legal, requirement.

As Saller observes (pp. 198-9), the assumption that the husband was intended to bear the onera matrimonii does not explain why dos adventicia remained with the husband at the wife's death, and the return of dos profecticia to the pater on the wife's death is not fully explained by the assumption that the dowry was intended to secure the possibility of the wife's remarriage. However, although maintenance and provision for remarriage were considerations underlying the general acceptance of the right of the wife and her father to recover dowry, the actual rules governing its return rest in the main on other principles, only partly on the notion of the dowry as part of the wife's patrimony or rather (almost but not quite the same thing) part of the property of the familia headed by her pater, and mainly on the legal consequences of the fact that in most cases (except in certain special circumstances, which will be mentioned presently) the actual specified dowry property had been legally conveyed into the ownership of the husband and became, for the duration of the marriage, his property. In no circumstances, therefore, did the dowry revert automatically at the end of the marriage; an action had to be brought for its recovery. If there had been a dotal agreement, the action would be based on that (actio ex stipulatu). Otherwise, there was an actio rei uxoriae. ${ }^{2}$

The actio rei uxoriae was available only to the wife or her pater. ${ }^{3}$ This is an important point. Although in practice outsiders could and did, like the younger Pliny, contribute to dowries, they had no right of recovery except ex stipulatu. The essence of dowry, in the eyes of the law, was the movement of property between two connected familiae - that headed by the husband or his pater and that headed by the wife's pater or, after his death, that constituted solely by the wife herself.

1 CQ 78 (1984), 195-205.

2 M. Kaser, Das Römische Privatrecht (1971), pp. 332-41; on the early history of the actio, see A. Watson, The Law of Persons in the Later Roman Republic (1967), p. 67.

3 P. E. Corbett, The Roman Law of Marriage (1930), pp. 182-8. 
Once these two principles are grasped, (i) that the dowry is the legal property of the husband during marriage, (ii) that the only other persons having a claim on it are the wife and her father, ${ }^{4}$ the rules for the return of the dowry are clear and consistent.

Dos adventicia was dowry which came from the daughter herself or from some other person, or which came from her father, not, however, in the last-mentioned case, by transfer of actual designated property but in other ways, for example, by his waiving a legacy in favour of the son-in-law, or in lieu of settlement of a debt (by acceptilatio or pactum de non petendo). Dos adventicia coming from the father in one of these ways was not recoverable by him, for reasons that should be obvious. If the wife died, dos adventicia remained with the husband. The father, if still alive, had no claim on it, since it had not come out of his actual property. An external donor had no claim (except ex stipulatu); his legal interest was at an end, since he had in law made an absolute gift to the husband. If the marriage ended in divorce or the husband's death, the dowry was recoverable by the wife, and only by her, for the reasons just stated. In other words, the husband did not retain dos adventicia at divorce, though he could still claim retentions for children, if he had not initiated the divorce, and various other retentions, e.g. propter impensas. The reasons for the dowry remaining with him at his wife's death have nothing to do with the presence or absence of onera but rest on his sole claim to legal ownership.

Dos profecticia was that given by the wife's father. If the marriage ended in divorce or the wife's death, he could bring an action for return of dowry against the husband. If the husband was the one who had died, an action had to be brought against his heirs, since the dowry, as part of his property, would pass with his estate. If the marriage ended in divorce after the death of the wife's father, his heirs could not bring an action since they had no claim to property that was not, at his death, part of his estate; only his daughter was held to have an action. In effect, on her father's death the dowry became dos adventicia, since the daughter was now sui iuris. She could reclaim it on divorce, but on her death it would remain with her husband. ${ }^{5}$

A dowry constituted by a father for an emancipated daughter was technically adventicia. Nevertheless, it was accepted, by the latter half of the first century A.D. at the latest, that this also could be reclaimed by the father at his daughter's death, as dos profecticia. Ulpian attributes this to family sentiment: 'It is not the right of potestas but the title of parent that makes a dowry profecticia'. Pomponius also explains that the law returns the dowry to a bereaved father as 'solace, so that he may not suffer the loss both of his daughter and of the money'.

More probably the acceptance of the father's claim in such circumstances rested originally on a principle similar to that which allowed emancipated children a share, but only after collatio bonorum, of the paternal estates - not so much family sentiment as the idea that the property belonged collectively to the familia, including cognati.

Children could be emancipated for a number of reasons, and sometimes in circumstances making it likely that there might be ill feeling between the generations. It may be remembered that Domitia Lucilla and the son of $\mathbf{M}$. Regulus were emancipated in order to receive inheritances, because the maternal grandfather of the former and (probably) the mother of the latter disliked and distrusted the children's

4 Father and pater are not necessarily identical (for instance, the pater might be the grandfather) but the two are used interchangeably here for convenience.

${ }^{5}$ On the rules for the constitution and recovery of dos adventicia and dos profecticia, see Ulp. Reg. 6.3-4; Frag. Vat. 116; Digest 23.3.5; Corbett, Law of Marriage, pp. 183-5; Watson, Persons, pp. 66-8.

${ }_{6}$ Digest 23.3.5.11, 6 pr. 
respective fathers and did not want them to get their hands on the estate. ${ }^{7}$ Where daughter and father were on bad terms there could be a conflict of interest. This sort of 'honorary' dos profecticia went to the father only in the event of his daughter's death; on divorce it was treated as dos adventicia. Not all families are happy ones, and two notices in the Digest show how a married couple could try to avail themselves of this loophole in order to prevent the wife's father recovering the dowry.

Ulpian says: 'If a daughter who has been emancipated gets a divorce in order that her husband may profit by her dowry and defraud her father, who otherwise could have claimed it as profecticia in the event of her death, the law should aid the father, to prevent his losing the dowry'. ${ }^{8}$

The dowry would go to the daughter on divorce, but the husband could claim retentions. In this instance, it is not clear that there is actually any question of the wife's imminent death; there could even have been a collusive divorce. The wife having recovered the dowry by actio rei uxoriae, it would legally become her property, and her father would have no further claim.

In a case discussed by the late second-century jurist Urseius Ferox but dating back at least to the latter half of the first century A.D., a father complained that the husband of his daughter (who was emancipated and was ill) divorced her, so that after her death he could give the dowry to her heirs rather than her father. Since the daughter was emancipated, the husband's case was presumably that the dowry became her property on divorce and at her death was part of her estate, to be disposed of as she wished. Legal opinion on the case was that the father should be allowed an equitable action for recovery. The lawyers were doing their best to plug the loophole, and siding with the pater, who stood to lose what was originally his, rather than with the husband.

Concerning the dowry as patrimony, Saller is correct in saying (p. 199) that there is nothing in classical law to suggest that the dowry was intended to satisfy the woman's claim to her father's estate. It should be noted, however, that the rules of collatio dotis ${ }^{10}$ originally applied differently to emancipated daughters and to those who were still in potestate at the time of the father's death. The former came under the same rules of collatio bonorum as any other emancipated children claiming a share in the estate. Emancipated children had been capable of possessing and acquiring property, while those in potestate had not, and the former were required by the praetorian edict to 'bring in' their property to the common amount for calculation of the division of the estate; if the woman's marriage was still in existence, she was required to give an undertaking that she would surrender an appropriate portion of the dowry to the other heirs when she acquired it. An emancipated daughter was unlikely to claim unless she stood to gain by doing so.

For much of the classical period, the edict did not apply if the daughter was still in potestate at the time of her father's death. Up to that moment, neither she nor any of the other heirs had had any independent legal capacity of owning property; the estate was decided on that basis, and no account was taken of the dowry. Obviously this could lead to unfairness to the other heirs if the woman later recovered her dowry, but for a long time nothing was done about it. The reason may have been that the sui heredes were originally unable to refuse estates on intestacy, and this could be a liability, if there was a heavy burden of debt. It would be inappropriate and unjust to expect dotal property (which in any case belonged to the woman's husband) to be

7 Pliny, Ep. 4.2, 8.18.

${ }^{8}$ Digest 24.2.5.

- Digest 24.3.59.

10 Digest 37.7; F. Schulz, Classical Roman Law (1951), pp. 229-32; W. W. Buckland, A Text-Book of Roman Law3 (1966), pp. 325-6; Kaser, $R P R^{2}, 732$. 
made to bear a share of that burden; a husband would in effect be being required to take on some of the debts of his late father-in-law. ${ }^{11}$ However, eventually, possibly not before the late Republic, the 'benefit of abstaining' (beneficium abstinendi) was introduced, ${ }^{12}$ giving heirs the power to abstain from the inheritance if they wished; if they did not, they were said to 'meddle with the inheritance' (bonis se immiscere). Antoninus Pius issued a rescript ${ }^{13}$ to the effect that a woman who did so should be required by the judge deciding the actio familiae erciscundae to 'bring in' her dowry. Even before this, it seems, the praetor had obliged her to 'bring in' the dowry if there had been a will and she had actively tried to upset it in order to claim part of the intestate succession. The only deduction allowed before collation was that for necessary expenses, none for any other cause.

A rescript of Gordian, which may either have been stating what was by then accepted practice or making a new ruling, stated that women sharing with brothers in potestate should 'bring in' both dos profecticia and dos adventicia; if they were sharing with emancipated brothers (who themselves had had means of acquiring property outside the paternal estate) they need 'bring in' only profecticia. 14 $^{4}$

If, besides having a dowry, a daughter had been included in her father's will, and another of his children tried to break the will, Ulpian's view was that the daughter would not be required to count in her dowry, so long as she accepted from the estate no more than had originally been left her in her father's will. This presumably meant that if the dowry was larger than the bequest it might in some cases be to her advantage to abstain from the inheritance. If the will was not challenged, of course, she could have both. ${ }^{15}$

All the same, inheritance has always been a subject likely to stir up bad feeling in families and, whatever the law said about the husband's legal ownership of dowry, brothers might be disposed to resent it as a pre-emption of patrimony, especially if the dowry turned out to exceed the share on division of the estate. Marcus Aurelius issued a rescript to settle one such quarrel. A daughter who was one of the sui heredes refused the estate, being content with her dowry (this presumably being to her advantage); her brothers wanted collation, to improve their shares. As the dowry had not yet been paid in full, they had a means of bringing pressure to bear. The emperor ruled that she could not be forced to 'bring in' her dowry and that the outstanding amount of dowry could be collected, as it was not part of the estate, but a debt on the estate. ${ }^{16}$

Finally, it is worth noticing that, although in practice most husbands did maintain their wives, there does not seem to have been any obligation upon them to do so, nor indeed to use the dowry for that purpose (the dowry itself being customary, but not compulsory). Our only evidence for a procedure to obtain maintenance is that of a hypothetical case put by Ulpian. ${ }^{17}$ A woman has gone mad. Her husband does not want to divorce her, because he wants to keep the dowry, but he is not maintaining her. Her father is apparently dead - Ulpian speaks later only of her curator and cognati - , so presumably Ulpian is deliberately setting up a situation in which the wife herself was legally incapable of getting a divorce. Her curator and cognati, he says, can appeal to a magistrate to have the husband compelled to give his wife maintenance,

11 Though dowry could be repaid voluntarily during marriage for such purposes as payment of debts in the wife's family: Corbett, op. cit., p. 198.

${ }_{12}$ Gaius, Inst. II. 158; Schulz, Classical Roman Law, pp. 281-2; Buckland, Text-Book, pp. 305, 395; Kaser, $R P R^{2}, 714 \mathrm{ff}$.

${ }_{13}$ Digest 37.7.1 pr.

14 C.6.20.4; Kaser, $R P R^{2}, 732$ n. 35.

15 Digest 37.7.3.

16 Digest 37.7.9.

${ }^{17}$ Digest 24.3.22.8. 
medical attention and all the care that it is seemly (decet - not, note, 'obligatory') for a husband to give his wife. However, the husband was to be compelled only up to the amount of the dowry. The inference is that, if there was no dowry, he could not be required to provide anything; but, if there was no dowry, this neglectful husband would presumably have no motive for retaining his wife. (There was, of course, the benefit obtained under the lex Julia et Papia Poppaea, but Ulpian does not include that consideration in his scenario.)

Absence of a specific legal obligation of maintenance is understandable. To impose such an obligation in a manus-marriage would have meant infringing the domestic sovereignty of the patria potestas. In this, as in the continuance of the transfer of dowry into the husband's ownership, the conservatism of Roman law had preserved elements that had originally been appropriate when the wife was absorbed into the husband's familia and was no longer among the sui heredes of her father, the marriage was permanent until her husband chose to end it, and the dowry, being irrecoverable, bore a patrimonial aspect. For the bride's father, the calculation in those circumstances was easy. He could fairly safely assume that both the dowry and the daughter were gone for good, and calculate the dowry accordingly, as a once-and-for-all charge upon his estate.

In later times, the financial calculations were much less simple. A father might hope for the best (i.e., for a stable and fruitful marriage) for his daughter; but he had to reckon also with the possibility that he might have to dower her twice or even oftener, recovering only part at the end of each marriage and having to 'top up'. In those circumstances, it made sense to keep the initial outlay down to what was necessary to secure her an acceptable husband, keeping something in reserve for later contingencies - whether for subsequent marriages or, ultimately, bequest directly to her. The pacta dotalia, and particularly those clauses, noticed by Saller (p. 198 and n. 16), stipulating for the return of the dowry not only to the pater himself but to his heirs, were probably an attempt to reduce the effects of these uncertainties still further by side-stepping the law, and ensuring that the dowry, or an agreed part of it, could always go back either to the wife or to her familia. This interpretation would accord with Saller's conclusion (p. 205) that the function of the dowry in the Principate was not primarily patrimonial but rather to provide for the support of the wife and her children in her husband's house. 